\title{
Aktifitas Membaca untuk Menelusuri Pesan Moral dalam Cerita Pendek Anak
}

\author{
May Triranto Maharini' ${ }^{1}$, Setiana Sri Wahyuni Sitepu² \\ Universitas Pamulang ${ }^{12}$ \\ Korespondensi: dosen01169@unpam.ac.id ${ }^{1}$, dosen01057@unpam.ac.id²
}

\begin{abstract}
This community service focuses on the theme of "Improving children's understanding of moral messages in children short stories through reading activities" and is held at RW 16 Kelurahan Benda Baru, Pamulanng 2. Every week, the children at RW 16 Kelurahan Benda Baru participate in routine informal activity to improve their skill in English. This routine activity is coordinated by its neighbourhood leader. This is to support the children to get knowledge that they possibly can not get at their school. There are three media used. They are English children short story reading texts, activity workbook for the children or the participants, and guidance video by the tutors from the community service of Universitas Pamulang. English children short story reading texts are the main medium used for the children or participants to understand moral messages through literature in the contexts of children's daily life. Next medium is the activity workbook made by the community service team of Universitas Pamulang for the children or participants to do the activities of reading and tasks related to the texts they read. The third medium is the video by the tutors to guide the children or participants to understand the instructions in the activity workbook. The result of reading activities supported by the three media mentioned before is that there is improvement of the participants' understanding regarding the moral messages and vocabulary in the children short stories.
\end{abstract}

Keywords: children short stories, community service, moral messages, reading activities

\begin{abstract}
Abstrak
Pengabdian kemasyarakatan ini mengangkat tema "Meningkatkan pesan moral dalam cerita pendek anak melalui aktifitas membaca". Kegiatn ini diadakan di RW 16 Kelurahan Benda Baru, Pamulang 2. Di setiap minggunya, anak-anak di RW 16 ini mengikuti kegiatan informal untuk meningkatkan kemampuan mereka dalam berbahasa Inggris. Kegiatan ini dikoordinir oleh pengurus RW setempat. Hal ini untuk mendukung mereka agar lebih dapat mengembangkan kemampuan mereka yang mungkin tidak mereka dapat di sekolah mereka. Tiga media utama yang digunakan dalam kegiatan pengabdian kemasyarakatan kali ini adalah teks bacaan cerita anak berbahasa Inggris, buku aktifitas peserta, video panduan dari para pembimbing. Teks bacaan anak berbahasa Inggris adalah media utama yang digunakan peserta untuk memahami pesan moral melalui kesusastraan dalam kontek kehidupan anak-anak. Kemudian buku aktifitas membaca dibuat oleh pembimbing dari Tim PkM yang merupakan teks bacaan cerita anak berbahasa Inggris berikut dengan instruksi-instruksi aktifitas membaca. Lalu video yang dibuat oleh para pembimbing yang merupakan mahasiswa Universitas Pamulang. Video ini diperuntukkan agar memudahkan para peserta mengerti dan memahami instruksi instruksi dalam buku aktifitas membaca yang diberikan pembimbing kepada peserta. Dari semua hal tersebut maka hasil yang didapat oleh Tim PkM adalah peningkatan pemahaman peserta mengenai pesan moral yang terkandung di dalam cerita berikut kosakatanya.
\end{abstract}

Kata kunci: aktifitas membaca, cerita anak, pengabdian kemasyarakatan, pesan moral 


\section{A. Pendahuluan}

Pengabdian Kegiatan Masyarakat kali ini diadakan dengan tujuan untuk mengembangakan karakter pada anak-anak yang sedang mengenyam pendidikan dasar. Hal ini sesungguhnya belum tentu terwujud secara tepat jika hanya mengandalkan dari pendidikan formal yaitu sekolah, mengingat begitu banyak objektif yang harus dipenuhi dalam level pendidikan formal. Berdasarkan hal itu, kegiatan kali ini berusaha untuk melengkapi hal tersebut demi tercapainya pendidikan karakter bagi anak. Sasaran dari kegiatan kali ini adalah anak-anak di RW 16 kelurahan Benda Baru Kecamatan Pamulang 2 Tangerang Selatan. Dipilihnya lokasi ini adalah untuk mendukung apa yang tidak didapat anak-anak tersebut di sekolah mereka.

Di setiap minggunya, anak-anak di RW 16 ini mengikuti kegiatan informal untuk meningkatkan kemampuan mereka dalam berbahasa Inggris. Kegiatan ini dikoordinir oleh pengurus RW setempat. Hal ini untuk mendukung mereka agar lebih dapat mengembangkan kemampuan mereka yang mungkin tidak mereka dapat di sekolah mereka. Dari kegiatan rutin ini, tim PkM mendapat informasi mengenai hal tersebut.

Peserta dalam kegiatan ini adalah anak-anak yang memiliki usia yang berkisaran 6 tahun sampai dengan 12 tahun. Masing-masing dari anak dengan kelompok usia tertentu di bagi dalam beberapa grup agar memudahkan kegiatan belajar mengajar informal ini untuk lebih mudah diikuti dan dipahami oleh mereka. Kegiatan yang rutin dilakukan tiap minggu ini membantu mereka untuk dapat berekspresi dengan aktif untuk merespon ilmu yang mereka dapat. Ekspresi yang dimaksud adalah mereka dapat menanyakan dan merespon segala informasi yang mereka terima.

Untuk mendapat ilmu diluar dari yang mereka pelajari di sekolah, kegiatan yang melibatkan pihak-pihak dalam organisasi yang dibentuk masyarakat RW16 kelurahan Benda Baru ini sangat memenuhi apa yang dibutuhkan oleh anak-anak warga keluarahan ini. Di sekolah, dalam pelajaran Bahasa Inggris, anak-anak ini hanya difokuskan untuk belajar Bahasa Inggris dasar. Bahasa Inggris dasar yang dimaksud adalah yang meliputi empat skill yaitu listening, speaking, reading, writing. Dalam hal motivasi belajar Bahasa Inggris, mereka kurang mendapat dorongan dari lingkungan formal. Padahal dengan motivasi yang mereka punya, pemahaman mereka dalam berbahasa Inggris akan lebih baik.

Meskipun motivasi untuk belajar Bahasa Inggris dalam konteks pengabdian kemasyarakatan yang dilakukan kali ini adalah bukan tujuan utama, tapi untuk merelevansikan dengan pendidikan karakter yang disandingkan pembelajaran Bahasa Inggris, ini adalah sangat penting dan berkaitan satu sama lainnya. Dengan alasan tersebut maka tema yang sesuai judul pengabdian kemasyarakatan ini adalah "Meningkatkan pemahaman pesan moral dalam Cerita Anak melalui Aktifitas Membaca".

Melalui tema ini, diharapkan menumbuhkan semangat anak-anak warga RW 16 kelurahan Benda Baru untuk belajar Bahasa Inggris diluar dari skill dasar yang hanya diajarkan di sekolah formal. Melalui kegiatan ini anak anak ini akan diberikan bahan bacaan yang buku cerita anak berahasa inggris yang menandung pesan moral dalam cerita tersebut. Ini adalah untuk menanamkan anak-anak tersebut pelajaran moral 
sejak dini sekaligus mereka dapat belajar Bahasa Inggris dan memahami konteks cerita dalam Bahasa Inggris.

Mengapa menggunakan buku cerita anak berbahasa Inggris untuk membuat mereka mengerti makna pesan tentang moral agar mereka dapat menerapkannya dalam kehidupan mereka sehari-hari? Mengapa tidak menggunakan platform lain? Alasan yang utama adalah perencana dan pelaksana pengabdian kemasyarakatan ini adalah dari Program Studi Sastra Inggris yang harus tetap memiliki tujuan untuk mengembangkan kemampuan Bahasa Inggris pada masyarakat.

Tema yang digunakan oleh pengabdian kemasyarakatan ini dapat direlasikan dengan pengasahan kemampuan anak dalam memahami teks bacaan berbahasa Inggris dan juga untuk pengenalan kesusastraan anak berbahasa Inggris. Pengasahan dalam memahami teks bacaan berbahasa Inggris bisa juga disebut sebagai peningkatan kemampuan literasi, terutama pada anak-anak. Karena yang dibahas dalam PkM ini adalah bersama anak-anak, dan anak-anak sebagai objek, maka kesusastraan yang digunakan adalah buku cerita anak. Dengan sastra sebagai manifestasi kehidupan manusia, maka anak-anak peserta $\mathrm{PkM}$ ini diharapkan mendapatkan efek yang baik dengan mempelajari dan memahami teks bacaan anak berbahasa Inggris lalu menyerap makna moral yang terkandung di dalamnya. Dalam hal ini, dikarenakan selama ini anak-anak hanya belajar Bahasa Inggris berdasarkan kosakatanya saja, termasuk ketika mereka belajar di sekolah, maka perlu diterapkan juga pembelajaran di luar pembalajaran kosakata atau grammar saja.

Seperti diketahui, salah satu hal yang penting untuk diajarkan kepada anak-anak adalah moral untuk kehidupan sehari-hari sejak dini. Dalam Kamus Besar Bahasa Indonesia (2008, p. 1059), tertera bahwa moral merupakan ilmu atau ajaran tenang baik atau buruknya hal yang diterima oleh khalayak atau secara umum. Sedangkan menurut Wantah (2005) moral merupakan sesuatu yang berkaitan dengan kemampuan individu dalam menentukan tingkah laku yang benar dan salah atau yang baik dan buruk. Untuk itu, pengabdian kemasyarakatan ini ingin menyampaikan kepada anakanak terutama di lingkungan RW 16 Kelurahan Benda Baru Pamulang 2 ini tentang pentingnya pesan moral untuk dimengerti oleh mereka melalui sebuah teks bacaan Bahasa Inggris.

Ada tiga hal penting yang diangkat tim pengabdian kemasyarakatan pada kegiatan kali ini, yaitu membaca, pesan moral, dan aktifitas dalam membaca. Untuk itu, perlu pemahaman lebih jelas mengenai hal tersebut. Di bagian ini, dijelaskan pendapat para ahli mengenai tiga hal tersebut.

Sesuai dengan tema dalam pengabdian kemasyarakatan ini, yaitu membacayang didukung dengan metode pembelajarannya, maka perlu dipaparkan bahwa pentingnya literasi menurut para ahli. Menurut Elizabeth Sulzby (1986), literasi ialah kemampuan berbahasa yang dimiliki oleh seseorang dalam berkomunikasi "membaca, berbicara, menyimak dan menulis" dengan cara yang berbeda sesuai dengan tujuannya. Sedangkan menurut Harvey J. Graff (2006), literasi ialah suatu kemampuan dalam diri seseorang untuk menulis dan membaca. Di sini berarti seperti yang dinyatakan Sulzby, bahwa kemampuan untuk dapat menyimak-walaupun dalamkonteks pengabsdian kemsayarakatan ini dikhususkan dalam memahami isi bacaan-bisa menjadi tolak ukur sebuah kemampuan bahasa. Selain kemampuan 
literasi, perlu juga untuk memperkenalkan anak-anak kepada dunia sastra, yaitu sastra anak. Perlu diketahui, sastra menurut Mursal Esten (1978) adalah pengungkapan dari fakta artistik dan imajinatif sebagai manifestasi kehidupan manusia (dan masyarakat) melalui bahasa sebagai medium dan memiliki efek yang positif terhadap kehidupan manusia (kemanusiaan). Dengan begitu, diperkenalkannya sastra yang untuk kegiatana kemasayarakatan ini adalah cerita anak, adalah penting. Karena hal tersebut adalah medium yang dapat digunakan guna memberikan outcome positif bagi kemanusiaan.

Selain literasi, pengabdian kemasyarakatan ini juga menekankan kepada pesan moral yang didapat setelah membaca. Kamus Besar Bahasa Indonesia (2016) memberi makna bahwa moral adalah ilmu tentang baik atau buruknya hal yang diterima oleh khalayak pada umunya. Selain itu, seorang ahli, yaitu Wantah (2005) menyebutkan bahwa moral adalah hal yang berhubungan dengan kemampuan seorang manusia untuk menentukan benar dan salah atau yang baik dan buruk sebuahperilaku. Dari sini, terlihat jelas bahwa dalam hidup bermasyarakat, manusia bukanlah makhluk individual yang tanpa batasan dalam berperilaku, karena bagaimanapun juga manusia tetap terelasi dengan manusia lainnya. Hal ini merupakan tolak ukur seorang individu berperilaku agar tidak terpusat pada kepuasan individu itu belaka, namun juga tidak merugikan manusia lainnya.

Yang terakhir, yang menjadi wadah para pembimbing dalam kegiatan ini adalah metode kegiatan dalam membaca. Menurut Anderson (1999) membaca adalah proses aktif yang mana pembaca dapat berinteraksi dengan teks bacaan berdasarkan latar belakang pengetahuan dan pengalaman mereka. Lebih dari itu, menurut Grellet (1981, p. 7) pembaca dapat menggunakan lebih dari satu strategi untuk memahami teks bacaan. Sedangkan Ebrahimi (2012) menyatakan bahwa membaca adalah proses yang kompleks dan juga interaktif yang melibatkan karakter pembaca, teks, dan fungsinya.

Berdasarkan yang dikemukakan para ahli tersebut, maka tema "Mengenal Pesan Moral dalam Cerita Anak melalui Aktifitas Membaca" dapat membantu anak-anak di lingkungan RW 16 Kelurahan Benda Baru Pamulang 2 ini mendapat pengalaman pembelajaran melalui aktifitas membaca. Namun, berdasarkan hal tersebut dan juga melalui kegiatan ini, ada sebuah masalah atau pertanyaan yang perlu dijawab: Apakah benar bahwa aktifitas membaca dapat menjadi wadah bagi anak-anak untuk dapat meningkatkan pemahaman moral yang terkandung dalam buku cerita anak berbahasa Inggris?

Dengan ini pula diharapkan kegiatan ini akan memberikan sejumlah manfaat diantaranya: 1) Bagi para anak-anak di lingkungan RW 16 Kelurahan Benda Baru Pamulang 2, kegiatan ini diharapkan dapat memberikan wadah untuk penambahan ilmu pengetahuan terutama dalam metode membaca, memahami isi bacaan (terutama yang berbahasa Inggris), dan mengenal pesan moral yang dapat berlaku di kehidupan sehari-hari; 2) Bagi para civitas akademika dan dosen Prodi Sastra Inggris, pengabdian masyarakat ini dapat dijadikan sebagai wahana yang tepat untuk mengamalkan ilmu serta sebagai wujud dari pengabdian masyarakat yang merupakan bagian dari Tri Dharma Perguruan Tinggi; 3) Kegiatan ini diharapkan dapat memperkaya akhlak moral dan kosakata peserta melalui aktifitas membaca cerita dalam Bahasa Inggris. 
May Triranto Maharini \& Setiana Sri Wahyuni Sitepu

\section{B. Pelaksanaan dan Metode}

Sebagai metode pelaksanaan, ada beberapa hal penting dalam kegiatan kemasyarakatan ini yang diperhatikan dan kemudian direncanakan oleh tim PkM. Metode pelaksanaan ini berikut dijelaskan pada bagian ini di mulai dari tempat, waktu, peserta, dan juga urutan kegiatan yang dilakukan. Sebelum masuk ke tahap pertama kegiatan inti, tim berusaha mewawancarai atau memberikan pertanyaan kepada anakanak tersebut tentang seberapa besar yang mereka dapat dari pembelajaran formal Bahasa Inggris berkenaan dengan pengembangan karakter mereka. Dari jawaban mereka, diukur apakah mereka sudah cukup dalam mendapatkan ilmu karakter dasar melalui program formal Bahasa Inggris tersebut di sekolah. Setelah ini, barulah kegiatan masuk ke kegiatan inti.

Tahap pertama adalah para pemimbing atau mahasiswa memberikan cerita anak kepada para peserta untuk dibaca dan dipahami. Para peserta dididik untuk dapat membaca buku cerita anak berbahasa Inggris dan berusaha memahami konteks dan isi yang terkandung dalam cerita-cerita tersebut. Kemudian ada beberapa strategi yang dikreasikan oleh para pembimbing sebagai aktifitas membaca para peserta. Aktifitas ini diharapkan memberikan hasil berupa alat ukur pemahaman para pesertamengenai isi teks bacaan cerita anak berbahasa Inggris.

Tahap kedua adalah pembuatan atau penjilidan buku yang dilakukan oleh tim PkM. Buku ini berfungsi sebagai buku aktifitas membaca untuk para peserta. Buku ini diperuntukkan sebagai media yang dapat membantu peserta memahami isi cerita, makna moral yang terkandung di dalam ecrita tersebut. Dakam buku ini pula terdapat instruksi-instruksi bagi peserta untuk melaksanakan aktifitas membaca. Inilah nanti yang dijadikan sebagai alat ukur peserta dalam memahami isi teks cerita anak berbahasa Inggris.

Tahap ketiga adalah para pembimbing membuat video sebagai guidance. Maksudnya, video ini dibuat untuk para peserta agar dapat mengikuti dan memahami buku aktifitas membaca tersebut. Peserta memang diharapkan dapat memahami teks bacaan cerita anak berbahasa Inggris, namun dengan video ini diharapkan pula mereka memahami dan mengerti instruksi dalam buku tersebut. Sebab dengan pemahaman yang tepat, para peserta dapat melakukan aktifitas-aktifitas membaca secara benar. Dengan begitu, hasil yang didapat dari aktifitas-aktifitas tersebut dapat terlihat jelas. Hasil jelas yang dimaksud adalah bahwa peserta bisa memahami pesan moral dalam cerita berbahasa inggris tersebut melalui kegiatan aktifitas membaca.

Tahap yang terakhir adalah kegiatan pertemuan daring. Melalui pertemuan daring ini para panitia dapat melihat, menganalisa, dan menyimpulkan bagaimana peserta dapat memperlihatkan hasil yang didapat setelah membaca dan melakukan aktifitas membaca (sebelum membaca, ketika membaca, dan setelah membaca) dengan memahami lalu memberikan respon atas pertanyaan dan instruksi dalam aktifitas membaca.

\section{Khalayak Sasaran, Tempat, dan Waktu}

Berikut ini tempat, sasaran, dan waktu pelaksanaan kegiatan pengabdian masyarakat adalah sebagai berikut: 
1. Tempat Kegiatan : RW 16 kelurahan Benda Baru Pamulang 2

2. Sasaran Kegiatan : Siswa usia Sekolah Dasar (10 - 12 tahun)

3. Waktu Pelaksanaan Kegiatan

Hari/Tanggal : 15, 16, 17 Desember 2020

Waktu $: 14.00-17.00$.

Kegiatan PkM ini melibatkan mahasiswa Universitas Pamulang dalam menyiapkan materi cerita berbentu teks bacaan yang akan disampaikan kepada peserta PkM yaitu anak-anak RW 16 Kelurahan Benda Baru Pamulang 2. Kemudian untuk menyesuaikan dengan situasi yang ada, yaitu masih dalam masa pandemi COVID-19, tim PkM memutuskan untuk menyampaikan materi teks tersebut secara virtual/online dengan pembuatan video. Video ini diberikan kepada anak-anak anak RW 16 Kelurahan Benda Baru Pamulang 2. Untuk hasil dapat dianalisa bagaimana reaksi anak-anak tersebut terhadap video tersebut dan bagaimana pemahaman mereka yang didapat dari video tersebut yaitu dengan aktifitas membaca (pre-reading, while reading, post-reading activities).

\section{Metode Kegiatan}

Apresiasi terhadap puisi-puisi tersebut akan dilaksanakan melalui tahapantahapan pelaksanaan sebagai berikut:

Tabel 1. Kegiatan dan pelaksanaan

\begin{tabular}{|c|c|c|}
\hline No & Kegiatan & Pelaksana \\
\hline 1 & $\begin{array}{l}\text { Diskusi para pebimbing dari } \\
\text { tim PkM }\end{array}$ & $\begin{array}{l}\text { Dosen dan Mahasiswa } \\
\text { Unpam }\end{array}$ \\
\hline 2 & Pengumpulan materi & Mahasiswa Unpam \\
\hline 3 & $\begin{array}{l}\text { Pembuatan buku lembar kerja } \\
\text { atau lembar aktifitas membaca } \\
\text { untuk peserta }\end{array}$ & Mahasiswa Unpam \\
\hline 4 & $\begin{array}{l}\text { Pembuatan video berdasarkan } \\
\text { buku lembar kerja atau lembar } \\
\text { aktifitas membaca untuk } \\
\text { peserta yang sudah dibuat }\end{array}$ & $\begin{array}{l}\text { Dosen dan Mahasiswa } \\
\text { Unpam }\end{array}$ \\
\hline 5 & $\begin{array}{l}\text { Penyampaian video kepada } \\
\text { peserta }\end{array}$ & $\begin{array}{l}\text { Mahasiswa Unpam dan } \\
\text { peserta }\end{array}$ \\
\hline 6 & $\begin{array}{l}\text { Pengamatan tim PkM terhadap } \\
\text { hasil metode ajar yang } \\
\text { diperlihatkan oleh peserta } \\
\text { melalui aktifitas membaca } \\
\text { lewat video yang dibuat tim } \\
\text { PkM beserta buku lembar } \\
\text { kerja.aktifitas membaca }\end{array}$ & $\begin{array}{l}\text { Dosen, mahasiswa } \\
\text { Unpam, peserta }\end{array}$ \\
\hline 7 & $\begin{array}{l}\text { Penutupan dan analisa beserta } \\
\text { kesimpulan dari kegiatan PkM } \\
\text { kali ini. }\end{array}$ & $\begin{array}{l}\text { Dosen dam mahasiswa } \\
\text { Unpam }\end{array}$ \\
\hline
\end{tabular}


May Triranto Maharini \& Setiana Sri Wahyuni Sitepu

\section{Hasil dan Pembahasan}

Dalam bagian ini dijelaskan mengenai hasil yang didapat setelah pelaksanaan PkM yang bertema "Meningkatkan pemahaman pesan moral dalam cerita anak melalui aktifitas membaca” di RW 16 Kelurahan Benda Baru Pamulang 2.

Seperti dijelaskan pada bagian sebelumnya bahwa kegiatan ini adalah bertujuan untuk membuat anak-anak peserta kegiatan ini dapat mengerti dan memahami pesan moral yang terkandung dalam cerita anak berbahasa Inggris. Anak-anak diwawancarai oleh panitia seberapa besar mereka telah pernah mendapatkan pendidikan dasar karakter melalui pelajaran Bahasa Inggris. Ada 3 responden yang diwawancara. Hasilnya, seperti yang tertera pada tabel berikut:

Tabel 2. Interview pre-activity

\begin{tabular}{|c|c|c|}
\hline No & Pertanyaan & Respon \\
\hline 1. & $\begin{array}{l}\text { Pernahkah membaca buku cerita anak berbahasa } \\
\text { Inggris ketika pelajaran Bahasa Inggris di } \\
\text { Sekolah? }\end{array}$ & $\begin{array}{l}2 \text { anak menjawab tidak, } 1 \\
\text { anak menjawab pernah. }\end{array}$ \\
\hline 2. & $\begin{array}{l}\text { Buku cerita anak berbahasa Inggris kira-kira } \\
\text { ceritanya tentang apa? }\end{array}$ & $\begin{array}{l}\text { "Cerita tentang anak- } \\
\text { anak" (jawaban anak } \\
\text { pertama), "cerita seperti } \\
\text { superhero" (jawaban } \\
\text { anak kedua), "banyak" } \\
\text { (jawaban anak ketiga) }\end{array}$ \\
\hline 4. & $\begin{array}{l}\text { Apakah mendapat kata-kata baru (kosakata } \\
\text { Bahasa Inggris) setelah membaca buku cerita } \\
\text { anak berbahasa Inggris? }\end{array}$ & $\begin{array}{l}\text { Dua anak menjawab "iya" } \\
\text { dan satunya menjawab } \\
\text { "kadang-kadang." }\end{array}$ \\
\hline 5. & $\begin{array}{l}\text { Apakah berminat untuk membaca buku cerita } \\
\text { anak berbahasa Inggris jika sedang belajar } \\
\text { Bahasa Inggris? }\end{array}$ & $\begin{array}{l}\text { Mereka semua menjawab } \\
\text { "iya". }\end{array}$ \\
\hline
\end{tabular}

Dari wawancara sebelum kegiatan, tampak bahwa anak-anak tersebut belum mengenal dengan jelas bahwa dengan membaca dapat memberikan mereka pengetahuan mengenai apa yang baik dan apa yang tidak baik dalam berperilaku untuk keseharian mereka. Tapi mereka menyadari bahwa dengan membaca teks berbahasa Inggris mereka dapat mempelajari kata-kata baru Bahasa Inggris. Mereka juga berminat untuk membaca buku cerita anak berbahasa Inggris ketika sedang belajar Bahasa Inggris. Melihat dari hasil ini, maka diharapkan mereka dapat menangkap pesan moral yang terkandung dalam buku cerita anak berbahasa Inggris, bukan saja untuk menambah kosakata Bahasa Inggris mereka. 
Permasalahan lainnya adalah bahwa kita sedang dalam keadaan pandemi. Pertengahan Maret tahun 2020 ini tanpa setiap warga Negara Indonesia atau bahkan Negara dunia dapat peridiksi sebelumnya, muncul pandemic wabah penyakit korona. Wabah ini mempengaruhi segala aspek kehidupan warga dunia, termasuk Indonesia. Setiap sekolah dan perkuliahan pun diliburkan karena wabah penyakit korona ini. Ini disebabkan karena wabah ini dapat cepat sekali menular speerti penyakit influenza. Maka setiap pergumulan yang bersifat masal seperti system belajar di dalam ruang kelas yang melibatkan banyak orang dalam satu ruangan tersebut tidak diperbolehkan hingga sampai saat ini. Untuk menghindari hal itu maka ada beberapa solusi yang dilakukan dalam kegiatan ini dalam situasi pandemi seperti ini.

Berikut ini adalah tabel kegiatan inti yang merupakan solusi dari permasalahan yang ada, dimana kurangnya anak-anak dalam mendapatkan kesempatan untuk memahami pesan moral yang terkandung dalam buku cerita anak berbahasa Inggris yaitu dengan implementasi aktifitas membaca buku cerita anak berbahasa Inggris.

Tabel 3. Kegiatan pembelajaran dan output

\begin{tabular}{|c|c|c|}
\hline No & Kegiatan Pembelajaran & Output \\
\hline 1. & $\begin{array}{l}\text { Menyediakan cerita-cerita folktale } \\
\text { yang diperuntukkan untuk anak-anak } \\
\text { herbahasa Inogris }\end{array}$ & $\begin{array}{l}\text { Sebagai alat ukur pemahaman para } \\
\text { peserta mengenai isi teks bacaan } \\
\text { cerita anak herbahas Inogris }\end{array}$ \\
\hline 2. & $\begin{array}{l}\text { Menyediakan buku aktifitas membaca } \\
\text { yang di dalamnya terdapat teks } \\
\text { bacaan cerita anak berbahasa Inggris. }\end{array}$ & $\begin{array}{l}\text { Buku aktifitas sebagai tolak ukur } \\
\text { yang dibuktikan dengan jawaban } \\
\text { yang diberikan peserta atas } \\
\text { pertanyaan tentang moral yang } \\
\text { terkandung dalam cerita dan tentang } \\
\text { beberapa pemahaman kosakata } \\
\text { dalam cerita tersebut. }\end{array}$ \\
\hline 3. & $\begin{array}{l}\text { Menyediakan video sebagai guidance } \\
\text { untuk para peserta agar dapat } \\
\text { mengikuti dan memahami buku } \\
\text { aktifitas membaca tersebut. }\end{array}$ & $\begin{array}{l}\text { Sebagai fasilitas untuk memudahkan } \\
\text { peserta dalam memahami instruksi } \\
\text { yang disampaikan pembimbing } \\
\text { melalui video dan dapat } \\
\text { mengungkapkan pesan moral dalam } \\
\text { cerita berbahasa inggris dengan } \\
\text { melakukan kegiatan aktifitas } \\
\text { membaca. }\end{array}$ \\
\hline 4. & Pertemuan daring & $\begin{array}{l}\text { Sebagai fasilitas } \\
\text { mendiskusikan hasil yang tampak } \\
\text { dengan diberlakukannya metode } \\
\text { pembelajaran aktifitas membaca } \\
\text { dengan tujuan untuk menangkap } \\
\text { pesan moral dari cerita yang } \\
\text { disajikan. }\end{array}$ \\
\hline
\end{tabular}


Hal pertama adalah dengan menyediakan cerita cerita folktale yang diperuntukkan untuk anak-anak dari berbagai Negara yang menggunakan Bahasa Inggris. Para pemimbing memberikan cerita anak ini kepada para peserta untuk dibaca dan dipahami. Jadi di sini para peserta dididik untuk dapat membaca buku cerita anak berbahasa Inggris dan berusaha memahami konteks dan isi yang terkandung dalam cerita-cerita tersebut. Kemudian untuk mengasah dan menguji pemahaman mereka pada cerita-cerita tersebut ada beberapa strategi yang dikreasikan oleh para pembimbing sebagai aktifitas membaca yang diharapkan memberikan hasil. Hasil dalam hal ini adalah pemahaman anak tentang pesan moral yang terkandung dalam cerita-cerita tersebut.

Agar cerita-cerita tersebut mudah dimengerti berikut dengan insttruksi aktifitas membacanya, maka pembuatan atau penjilidan buku akan dilakukan oleh tim PkM. Dengan menggunakan buku yang berfungsi sebagai buku aktifitas membaca untuk para peserta tersebut, diharapkan para peserta mendapat media yang dapat mengantarkan mereka pada pemahaman terhadap isi cerita, makna moral yang terkandung di dalam cerita tersebut, berikut juga dengan melaksanakan aktifitas yang dapat dijadikan sebagai alat ukur sejauh mana mereka memahami isi teks cerita tersebut.

Selanjutnya para pembimbing juga membuat video sebagai guidance untuk para peserta agar dapat mengikuti dan memahami buku aktifitas membaca tersebut. Video guidance ini, selain untuk dapat memahami teks bacaannya itu sendiri, peserta diharapkan juga memahami dan mengerti apa yang diinstruksikan dalam buku tersebut. Dengan memahami hal iitu, para peserta dapat melakukan aktifitas-aktifitas membaca secara benar, sehingga hasil yang didapat dari aktifitas-aktifitas tersebut akan jelas terlihat. Hasil yang diharapkan yang dimaksud di sini adalah bahwa peserta bisa memahami pesan moral dalam cerita berbahasa inggris tersebut dan dapat mengekspresikannya melalui aktifitas-aktifitas membaca.

Buku aktifitas peserta, video guidance dari para pembimbing, dan juga pertemuan daring di sini menjadi media utama yang digunakan dalam kegiatan pengabdian kemasyarakatan kali ini sebagai bentuk kepedulian tim PkM pada pengembangan kemampuan peserta dalam memahami pesan moral bacaan cerita anak berbahasa Inggris dan untuk mengekspresikannya. Pertemuan virtual diadakan untuk melihat peserta dalam mengekspresikan apa yang mereka sudah pahami dari video dan juga buku aktifitas membaca. Dari semua hal tersebut maka tim PkM dapat mengukur hasil dari keberhasilkan kegiatan pengabdian kemasyarakatan kali ini.

Sesuai yang telah dijelaskan bahwa tahap pertama yaitu para pembimbing atau mahasiswa memberikan cerita anak berbahasa Inggris kepada para peserta agar mereka dapat membaca dan memahaminya. Di sini, para peserta dididik dapat memahami isi yang terkandung dalam cerita tersebut. Cerita yang dipilih oleh para pembimbing adalah Tortoise and the Hare. Cerita ini mengisahkan tentang seekor kelinci yang merasa sombong karena dirinya lebih cepat daripada kura-kura. Sang kelinci pun mengejek sang kura-kura. Hingga sang kura-kura menerima tantangan untuk berlomba dengan sang kelinci siapa yang bisa mencapai garis akhir lebih cepat dalam berlari. Merasa jauh sudah jaraknya dengan sang kura-kura, sang kelinci pun 
tertidur. Ketika ia bangun, sang kura-kura sudah sampai di garis akhir lebih dahulu. Dengan cerita yang memiliki arti moral tersirat ini, ada beberapa strategi yang dikreasikan oleh para pembimbing sebagai aktifitas membaca untuk para peserta. Aktifitas ini ternyata dapat memberikan hasil berupa alat ukur pemahaman para peserta mengenai isi teks bacaan cerita anak berbahasa Inggris.

Setelah tahap sebelumnya yaitu adalah pembuatan atau penjilidan buku oleh tim PkM. Dengan buku ini peserta dapat memahami isi cerita dan makna moral yang tersirat dalam cerita.

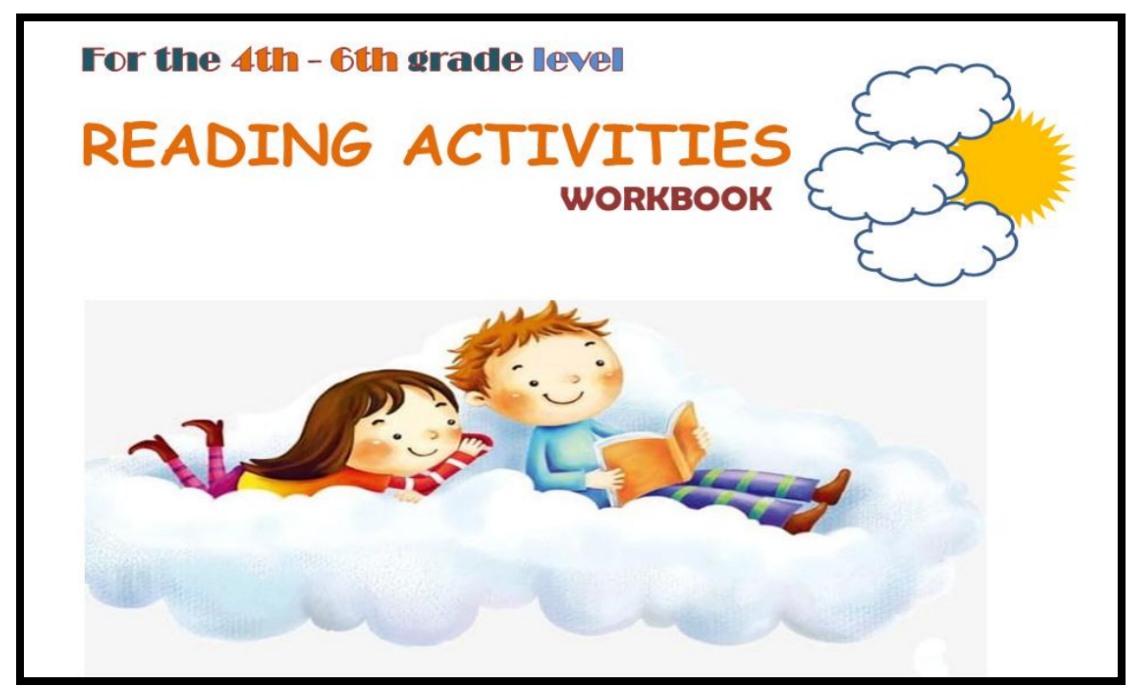

Gambar 1. Sampul buku aktifitas membaca

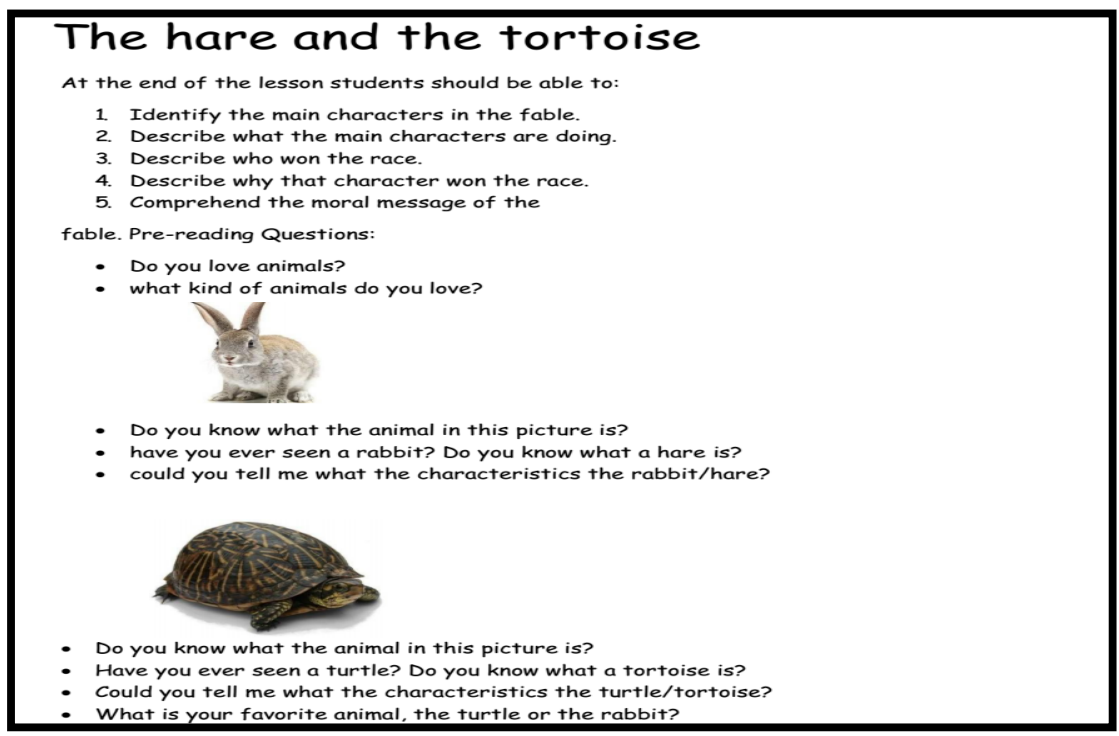

Gambar 2. Latihan dalam buku aktifitas membaca

Karena dalam buku terdapat instruksi-instruksi bagi peserta untuk melaksanakan aktifitas membaca. Instruksi dalam aktifitas membaca ini meliputi 


\section{May Triranto Maharini \& Setiana Sri Wahyuni Sitepu}

aktifitas sebelum membaca untuk melihat sejauh mana mereka dapat merelasikan fokus mereka pada tema teks yang akan dibaca oleh mereka, lalu aktifitas dalam membaca yang mana aktifitas ini lebih berpusat pada bagaimana cerita ini tersampaikan kepada mereka dalam menyimak (dalam hal ini yaitu dengan storytelling yang disampaikan pembimbing dalam video), dan yang terakhir adalah aktifitas setelah membaca yaitu para peserta menjawab pertanyaan seputar apa yang telah mereka pahami dari teks bacaan tersebut. Aktifitas setelah membaca menjadi tolak ukur bagi peserta dalam memahami isi teks cerita anak berbahasa Inggris. Tolak ukur ini telah dapat dibuktikan dengan jawaban yang diberikan peserta atas pertanyaan tentang moral yang terkandung dalam cerita dan tentang beberapa pemahaman kosakata dalam cerita tersebut.

Untuk mendukung buku lembar aktifitas membaca yang diperuntukkan bagi para peserta, tim pengabdian kemasyarakatan membuat video sebagai panduan.

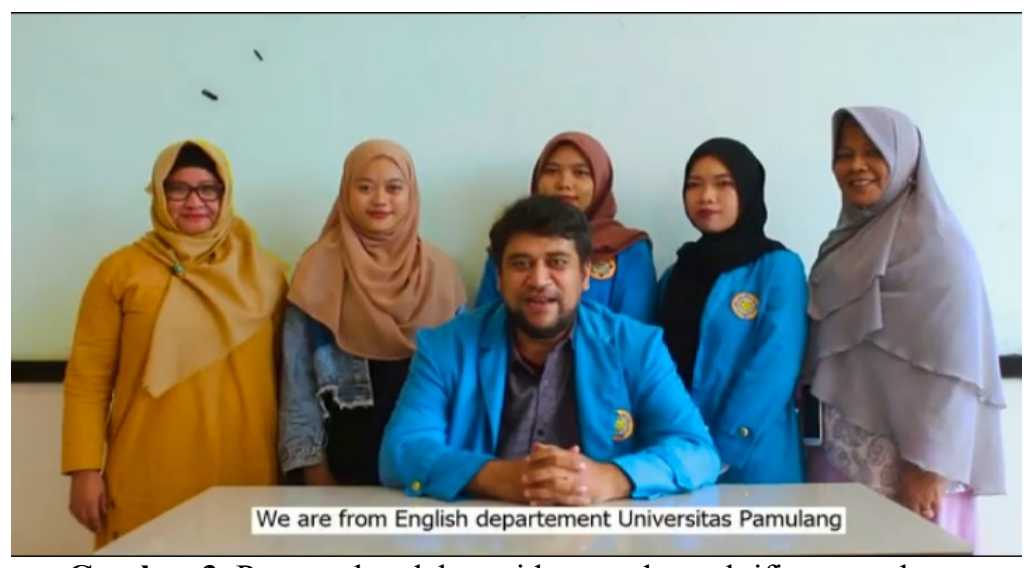

Gambar 3. Pengenalan dalam video panduan aktifitas membaca

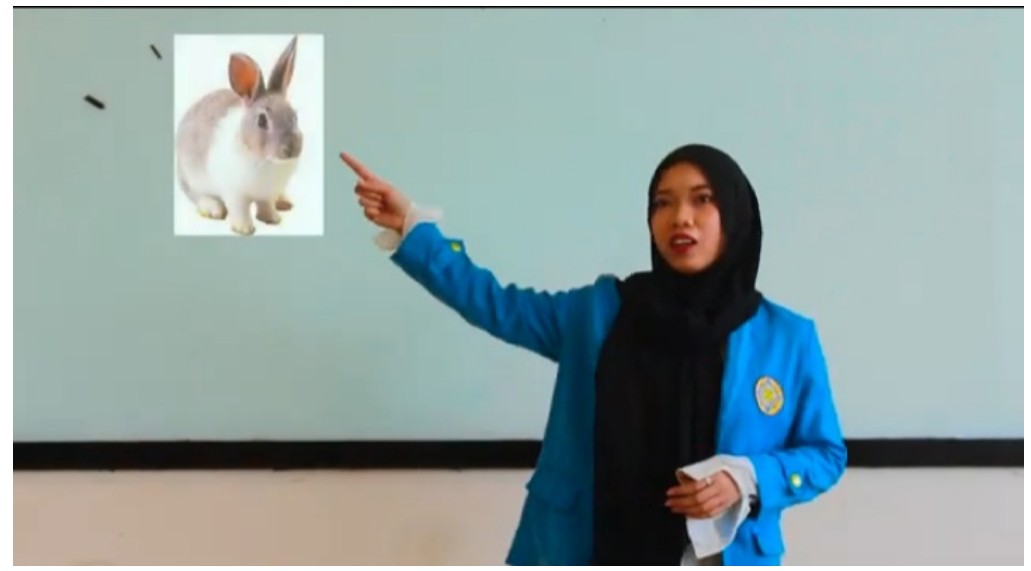

Gambar 4. Penjelasan dalam video panduan aktifitas membaca oleh mahasiswa Unpam 


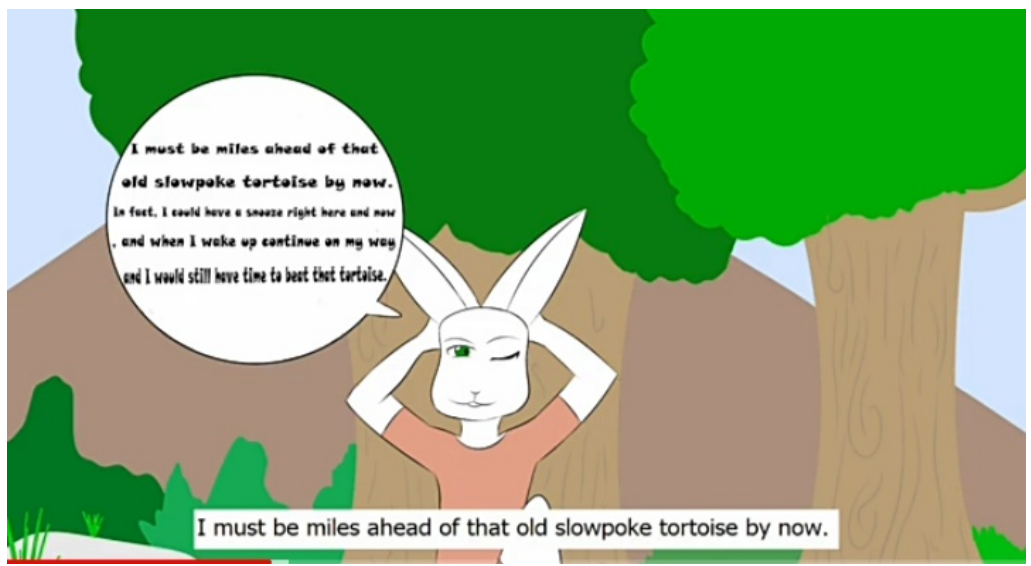

Gambar 5. Storytelling dalam video panduan aktifitas membaca oleh mahasiswa Unpam

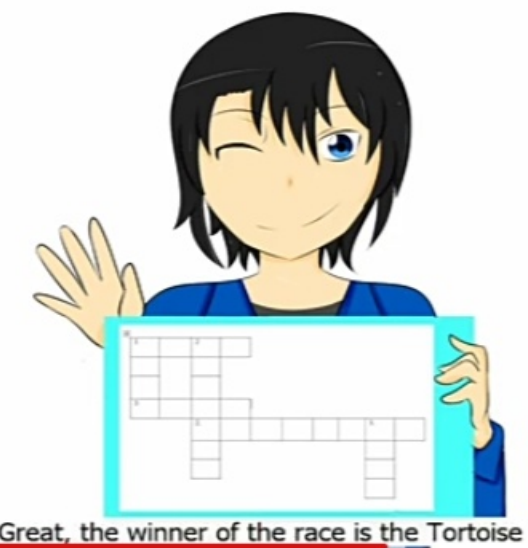

Gambar 6. Panduan mengerjakan aktifitas dalam video oleh mahasiswa Unpam

Dengan video ini peserta para peserta dapat mengikuti dan memahami buku aktifitas membaca tersebut dengan baik. Hasilnya mereka lebih dapat memahami dan mengerti instruksi yang terdapat dalam buku tersebut sehingga mereka dapat melakukan aktifitas-aktifitas membaca secara benar. Hasil jelas dari penyediaan video ini adalah bahwa mereka dapat memahami instruksi yang disampaikan pembimbing melalui video dan dapat mengungkapkan pesan moral dalam cerita berbahasa inggris dengan melakukan kegiatan aktifitas membaca.

Hasil yang terlihat didukung juga melalui diadakannya pertemuan daring. Dengan pertemuan daring ini para pelaku kegiatan pengabdian kemasyarakatan ini dapat melihat secara interaktif antara satu dan lainnya yang dengan ini para panitia atau tim PkM dapat menganalisa dan mendiskusikan hasil yang tampak dengan diberlakukannya metode pembelajaran aktifitas membaca dengan tujuan untuk menangkap pesan moral dari cerita yang disajikan. Hal ini didukung juga dengan hasil inteview dengan tiga anak lainnya-bukan responden yang ditanya pada saat pre- 
activity) — bahwa mereka memahami pesan moral yang terkandung di dalam buku cerita anak tersebut.

Tabel 4. Interview post-activity

\begin{tabular}{lll}
\hline No & Pertanyaan & Respon \\
\hline 1. & $\begin{array}{l}\text { Apakah senang dengan aktifitas membaca buku } \\
\text { cerita anak berbahasa Inggris pada kegiatan ini? }\end{array}$ & $\begin{array}{l}\text { Mereka semua menjawab } \\
\text { "iya". }\end{array}$
\end{tabular}

2. Buku cerita anak berbahasa Inggris yang dibahas Jawaban mereka: tadi ceritanya tentang apa?
1. Tidak boleh sombong,
2. jangan mengejek yang lebih lambat dari kita,

3. Jangan cepat puas.

4. Apakah mendapat kata-kata baru (kosakata

Mereka menjawab "iya”.

Bahasa Inggris) setelah membaca buku cerita anak berbahasa Inggris?

5. Apakah selanjutnya akan terus berminat untuk Mereka semua menjawab membaca buku cerita anak berbahasa Inggris jika sedang belajar Bahasa Inggris?

Dari tabel di atas, jawaban anak-anak tersebut menunjukkan bahwa mereka memahami pesan moral yang terkandung dalam cerita anak tersebut, dan juga belajar kosakata baru dari menyimak bacaan tersebut. Selain itu mereka juga berminat terhadap kegiatan aktifitas membaca ini untuk diimplementasikan kembali.

Dengan ini dapat dilihat bahwa kreatifitas dalam metode pembelajaran, yang salah satunya adalah aktifitas membaca-yang disajikan dalam bentuk buku lembar kerja/aktifitas dan video panduan, dapat membantu para anak atau peserta meningkatkan daya literasi mereka terutama dalam memahami pesan moral yang terkandung dalam cerita beserta kosakatanya.

\section{Penutup}

\section{Simpulan}

Pelaksanaan kegiatan pengabdian kemasyarakatan yang di adakan di RW 16 Kelurahan Benda Baru Pamulang 2 dengan tema "Meningkatkan pemahaman pesan moral dalam cerita anak melalui aktifitas membaca" berkontribusi untuk meningkatkan daya literasi anak-anak terutama di lingkungan tersebut. Selain daripada itu, kegiatan ini menambah wawasan peserta tentang pesan moral yang dapat 
mereka jalani didalam keseharian mereka melalui sebuah cerita. Kegiatan atau aktifitas membaca memiliki peranan penting untuk membantu mereka mencapai tujuan tersebut - memahami pesan moral dalam sebuah cerita beserta kosakata yang terdapat di dalamnya. Implikasi hasil yang didapat adalah kegiatan ini berhasil membuat para peserta yaitu anak-anak di lingkungan RW 16 Kelurahan Benda Baru Pamulang 2 lebih mengenal dan memahami bahwa dalam setiap cerita mengandung pesan moral di dalamnya untuk dapat dijalani di kehidupan mereka sehari-hari. Sedangkan untuk Tim PkM, kegiatan ini dapat disimpulkan dengan hasil yang jelas bahwa tolak ukur peserta dalam memahami isi dan pesan moral yang terkandung dalam cerita bisa disampaikan melalui bermacam aktifitas sebelum membaca, ketika membaca, dan sesudah membaca. Terutama aktifitas sesudah membaca dapat dijadikan tolak ukur bahwa peserta memahami pesan dalam teks bacaan tersebut.

\section{Saran}

Untuk kegiatan selanjutnya yang berhubungan dengan memahami pesan moral melalui aktifitas membaca, dapat dilakukan secara lebih dalam dan kreatif yang dapat menghasilkan kemampuan anak-anak atau peserta dari range usia yang lebih tua untuk lebih ahli dalam membaca karya sastra dan memahami teks bacaan. Dengan begitu banyak hal dapat lebih dievaluasi bagaimana tingkat kemampuan mereka dalam membaca, berbahasa, dan menerapkannya dalam kehidupan sehari-hari.

\section{DAFTAR PUSTAKA}

Ebrahimi, S. (2012). Reading strategies of iranian postgraduate english students living at esl context in the first and second language. International Proceedings of Economics Development and Research, 30, 195- 199.

Esten, M. (1978). Kesusastraan (pengantar, teori, dan sejarah). Angkasa.

Goodman, K. (1967). Reading: A psycholinguistic guessing game. Journal of the Reading Specialist, 6, 126- 135.

Graff, H. J. (2006). Literacy. Microsoft ${ }^{\circledR}$ Encarta ${ }^{\circledR}$ [DVD]. Redmond, WA: MicrosoftCorporation 2005.

Grellet, F. (1981). Developing reading skills. Cambridge University Press.

Moral. (2016). KBBI Daring. https://kbbi.kemdikbud.go.id/entri/moral

Teale, W. H., \& Sulzby, E. (1986). Emergent literacy: writing and reading. Ablex Publication Corp.

Wantah, M. J. (2005). Pengembangan disiplin dan pembentukan moral pada usia dini. Departemen Pendidikan Nasional 